Васькович Ірина Мирославівна кандидат економічних наук, доцент, доцент кафедри адміністративного та фінансового менеджменту Національного університету «Львівська політехніка», вул. Ст. Бандери 28а, м. Львів, 79013, тел.: (032)-258-26-30, e-mail: vaskovicirina8@gmail.com, https://orcid.org/00000002-8828-3900

\title{
ПУБЛІЧНЕ УПРАВЛІННЯ ЛІСОВИМ ГОСПОДАРСТОВОМ: СВІТОВА ПРАКТИКА
}

Анотація. Лісове господарство - це цілісна множина взаємовідносин між управлінням державного агентства лісових ресурсів й лісогосподарськими підприємствами та іншими структурами, що створює умови для їх діяльності, пов'язаної з вирощуванням, заготівлею та надання допоміжних послуг у лісовому господарстві для задоволення потреб відповідних споживачів. Стратегії сталого розвитку лісових господарств вкорінена в двох положеннях; по -перше, що екосистеми мають потенціал для оновлення, по -друге, що економічна діяльність та суспільні уявлення чи цінності, які визначають взаємодію людини 3 навколишнім середовищем, $\epsilon$ змінною для забезпечення довгострокової продуктивності та здоров'я екосистеми. Управління лісовими господарствами вирішує великий ряд проблем у задоволенні зростаючих вимог на тлі розвитку людської популяції при збереженні екологічних функцій здорових лісових екосистем. У статті авторки наводять аналіз ключових показників для національного сприятливого середовища, щоб отримати глобальне уявлення про прогрес у впровадженні спроможності та впровадження управління лісовими господарствами на національному та операційному рівнях. Також здійснено грунтовний аналіз особливостей сталого розвитку лісових господарств у різних країнах світу. Аналіз даних глобальної оцінки лісових ресурсів за 2020 рік (FRA) використовується для надання уявлення про поточний стан прогресу у впровадженні ефективних стратегій в управлінні лісовими господарствами. Лісове господарство охоплює адміністративні, економічні, правові, соціальні та технічні заходи, пов'язані зі збереженням та використанням природних лісів та лісових насаджень. Вона передбачає різні ступені втручання людини для захисту лісової екосистеми, іiі функцій та ресурсів для сталого виробництва товарів та надання екологічних послуг. Хоча цілі управління дуже різняться в різних країнах світу i включають охорону ресурсів в охоронюваних лісах та заповідниках, основною метою часто було виробництво деревної продукції. Основним принципом ведення лісового господарства 3 акцентом на виробництві деревини є «стійка врожайність» або збирання деревних приростів,

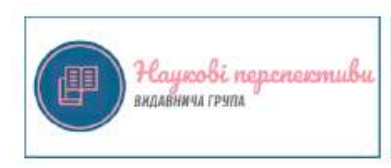


не витрачаючи при цьому на площі лісів. Дослідження присвячено аналізу основних тенденцій у світовій практиці управління лісовим господарством 3 метою формування пропозицій для застосування у вітчизняній практиці.

Ключові слова: лісове господарство, публічне управління лісовим господарством, сталий розвиток, екологічні системи, стратегії.

Vaskovych Iryna Myroslavivna Candidate of economic sciences, associate professor, associate professor of the department of administrative and financial management Lviv Polytechnic National University, St. Banderi St., 28a, Lviv, 79013, tel.: (032)-258-26-30, e-mail: vaskovicirina8@gmail.com, https://orcid.org/0000-00028828-3900

\section{PUBLIC FOREST MANAGEMENT: WORLD PRACTICE}

Abstract. Forestry is a whole set of relationships between the management of the state agency of forest resources and forest enterprises and other structures, which creates conditions for their activities related to cultivation, harvesting and provision of ancillary services in forestry to meet the needs of relevant consumers. Strategies for sustainable forestry development are rooted in two provisions; first, that ecosystems have the potential to renew, and second, that economic activity and the social perceptions or values that determine human interaction with the environment are variable to ensure the long-term productivity and health of the ecosystem. Forest management solves a number of problems in meeting the growing demands of the human population while preserving the ecological functions of healthy forest ecosystems. In the article, the authors provide an analysis of key indicators for a nationally favorable environment to gain a global picture of progress in capacity building and implementation of forest management at the national and operational levels. A thorough analysis of the features of sustainable forestry development in different countries of the world was also carried out. Analysis of the Global Forest Resources Assessment for 2020 (FRA) data is used to provide an overview of the current state of progress in implementing effective forest management strategies. Forestry covers administrative, economic, legal, social and technical measures related to the conservation and use of natural forests and forest plantations. It provides for varying degrees of human intervention to protect the forest ecosystem, its functions and resources for the sustainable production of goods and the provision of environmental services. Although management goals vary widely from country to country and include the protection of resources in protected forests and reserves, the main goal has often been the production of wood products. The main principle of forestry with an emphasis on wood production is "sustainable yield" or harvesting of wood growth, without spending on forest area. The study is devoted to the analysis of the main trends in the world practice of forest management in order to form proposals for application in domestic practice. 
Keywords: forestry, public forestry management, sustainable development, ecological systems, strategies.

Постановка проблеми. Лісове господарство - це мистецтво, наука та практика вивчення та управління лісами та насадженнями та відповідними природними ресурсами. Сучасне лісове господарство зазвичай виконує ряд функцій: допомагає забезпечити деревину як сировинний ресурс для виробів; $\epsilon$ середовищем існування дикої природи; $\epsilon$ основою для забезпечення якості природної води; є рекреаційною зоною, естетично привабливими ландшафтами та поглиначем вуглекислого газу в атмосфері.

Хоча лісове господарство зі стійкою врожайністю продовжує широко практикуватися, спостерігається зростаюча тенденція до управління лісами як екологічними системами з численними економічними вигодами та екологічними цінностями, а також із широкою участю громадськості у процесі прийняття рішень. Ця концепція загалом називається «стале управління лісами». Вона спрямована на те, щоб вигоди, як матеріальні, так і нематеріальні, отримані від лісу, задовольняли поточні потреби, водночас забезпечуючи їх постійну доступність та внесок у довгостроковий соціальний та економічний розвиток. На сьогодні $є$ достатньо технічних знань для розробки стійких систем виробництва деревини, які працюють у більшості екологічних ситуацій. Це також свідчить про наявність адекватних знань для виявлення та уникнення більшості лісових практик, які є нестійкими у ширшому сенсі. Таким чином, цілком ймовірно, що переважання нестійкої практики ведення лісового господарства у багатьох лісах світу є наслідком інших чинників, а не браку технічних знань.

Серед можливих факторів, що призводять до нестійкої практики ведення лісового господарства, фінансові наслідки різних систем управління лісами мають першочергове значення. Іншими словами, розумно очікувати, що без регулювання приватні інвестори, власники лісових земель, фермери та концесіонери лісоматеріалів будуть управляти своїми лісами екологічно, лише якщо це буде фінансово вигідно. Тому актуалізується питання аналізу особливостей публічного управління лісовими ресурсами у різних країнах світу на засадах забезпечення стійкого розвитку лісового господарства.

Аналіз останніх досліджень і публікацій. Теоретичну основу дослідження склали праці ряду зарубіжних та вітчизняних науковців. Зокрема дослідження комплексу заходів щодо забезпечення економічної, соціальної та екологічної сталості представив М. Віллямс[1]; особливості стійких систем управління в тропіках представили Дж. Рейд та Р. Райд [2]; особливості управління лісами досліджували Кіншон Н. та Константіно Р.[3] та ін. Серед вітчизняних науковців слід відзначити Б. Данилишина [4; 5], Д. Ветвицького [6], С. Дутки [7].

Однак, в наукових дослідженнях недостатньо систематизовано особливості національного управління лісовим господарством різних країн світу. 
Мета статті - дослідження особливостей та особливостей публічного управління лісовим господарством у різних країнах світу.

Виклад основного матеріалу. Стійке лісове господарство - це захист майбутнього нашої біосфери, забезпечення того, щоб у нас було «свіже повітря для дихання і чиста вода для пиття». Йдеться також про те, щоб глобальна економіка підтримувала свої потреби в деревині на сучасному етапі, а також у майбутньому, шляхом прийняття стратегій, які сприяють поповненню лісового ресурсу, робочих місць та здоровому екологічному середовищу, пропонуючи більше лісового простору для біорізноманіття. Важливим $\epsilon$ забезпечення майбутнього наших лісів, покращення середовища існування дикої природи та захист води.

Управління лісами є обов'язковою складовою системи лісового господарства, пов'язана із загальними адміністративними, правовими, економічними та соціальними елементами, а також науковими i технічними аспектами, такими як лісівництво, захист i лісовпорядкування. Це включає управління деревиною, естетикою , відпочинком , міськими цінностями, водою , дикою природою, внутрішнім i прибережним рибальством, деревною продукцією, генетичними ресурсами рослин та іншими цінностями лісових ресурсів. Цілі управління можуть бути збереженням, використанням або їх поєднанням. Хоча цілі управління дуже різняться і включають охорону ресурсів в охоронюваних лісах та заповідниках, основною метою часто було виробництво деревної продукції. Основним принципом ведення лісового господарства 3 акцентом на виробництві деревини є «стійка врожайність» або збирання деревних приростів, не витрачаючи при цьому на лісову столицю. Протягом останніх двох років було докладено значних зусиль для розробки загальних критеріїв на національному, регіональному та екорегіональному рівнях, за допомогою яких можна було б визначити стале управління лісами, а також для визначення показників, які можна використовувати для моніторингу та оцінки.

Тенденція до сталого управління лісами вносить значні зміни у сприйняття та використання лісів. Більше уваги приділяється управлінню лісами для виробництва недеревних лісопродуктів (ПЗП). Захисним функціям лісів приділяється більше уваги, що призводить до модифікованої практики господарювання. Суворі відмінності, які раніше проводилися між виробничими лісами, охоронними лісами та (природними) охоронними зонами, сьогодні стали більш розмитими. Наприклад: багато проектів розвитку та збереження сільських територій зосереджені на збільшенні виробництва деревних та недревесних лісопродуктів у “буферних зонах" як засобі зняття тиску з природоохоронних територій; підтримці захисних функцій приділяється більша увага у виробничих лісах; а роль лісів поза охоронюваними територіями у збереженні біологічного різноманіття вивчається більш ретельно.

Дотримуючись загальної тенденції до децентралізації, урядові управління лісового господарства багатьох країн, які розвиваються, докладають зусиль для 
децентралізації контролю над управлінням лісовими ресурсами. Це передбачає поступове перенесення відповідальності в межах профільних установ, від центрального до провінційного або районного рівня. Місцеві службовці отримали більші повноваження щодо прийняття рішень з питань місцевого управління. Це передбачає зміни в управлінській практиці на ті, які мають більш тісний зв'язок 3 місцевими умовами.

Другою важливою тенденцією є приватизація земельних ділянок або ведення лісового господарства. Ця тенденція має очевидні наслідки для ведення лісового господарства 3 точки зору збільшення прибутку, що стимулює прийняття управлінських рішень, а у випадку оренди та концесій - необхідності уряду контролювати операції для забезпечення дотримання узгоджених умов, пов'язаних із господарюванням.

Третя тенденція - забезпечення більшої участі широкого кола зацікавлених груп у процесі планування. Для цього потрібно, щоб лісові департаменти розвивали інституційну спроможність та здатність працювати з різними групами (що передбачало набагато більше зусиль, ніж у минулому, у сфері комунікації, надання консультацій та посередництва) i були здатні ефективно змінювати плани та методи управління для досягнення погоджених цілей. Нарешті, існує тенденція до заохочення більшої участі місцевих громад у управлінні лісовими ресурсами.

Децентралізоване управління лісовими ресурсами розглядається не тільки як засіб заохочення сталого лісового господарства, але також є прагматичною відповіддю на обмеження, що накладаються на лісові департаменти через їх скорочення фінансових та людських ресурсів. Розвиток систем управління за участю громадян, у яких місцеві громади відіграють важливу роль у повсякденному управлінні та захисті лісових ресурсів, у багатьох країнах, що розвиваються, відбувався стрімко, що призвело до широкого розмаїття механізмів управління, сформованих відповідно до місцевих умов. До них належать: спільне ведення лісового господарства; програми лісового господарства громади; комплексні програми збереження та розвитку, що використовуються переважно разом із зусиллями 3 охорони природи; та сільськогосподарське .

Спільне ведення лісового господарства - підхід до спільного управління, який був прийнятий у ряді штатів Індії та в деяких країнах Південно -Східної Азії, мав певні успіхи. Він грунтується на принципі, згідно 3 яким місцеві громади беруть безпосередню участь у управлінні громадськими лісами і при цьому отримують пряму вигоду від використання лісів. У Непалі підхід Національної програми лісового господарства для громади полягав у переговорах щодо угоди щодо лісового господарства між лісовим департаментом та групами користувачів (групи людей, які мають безпосередній інтерес у використанні певного лісу i які претендують на права користувачів). Групи користувачів беруть участь у розробці оперативного плану, і існує високий рівень місцевого 
контролю, хоча остаточні повноваження залишаються за дільничним офіцером лісового господарства. в обох випадках [8].

Стійка практика ведення лісового господарства вимагає таких заходів, як топографічне картографування, інвентаризація лісів, розмежування та розмежування кордонів, вирішення земельних суперечок та домовленостей щодо правовласності земель та підготовка планів управління лісом. Деяку площу доведеться відвести від комерційного виробництва деревини, що ще більше зменшить рентабельність (IPF, 1996). У більшості випадків стійкі методи ведення лісового господарства також потребуватимуть моніторингу та охорони для запобігання незаконному захопленню земель. Крім того, ці методи передбачають потребу в більш інтенсивних і ретельних лісокультурних обробках, включаючи захист від шкідників і вогню, а також ретельніші технології збирання. Хоча ці додаткові витрати на стале ведення лісового господарства, очевидно, сильно різняться між країнами та регіонами, Інтенсивність ведення лісового господарства варіюється від відпустки, природного стану до надзвичайно інтенсивного режиму 3 лісокультурними втручаннями. Застосування інноваційних підходів лісокористування повинні базуватися на цільовому прозорому використанні лісів, підвищення їх стійкості та ефективності, а також посилення екологозахисних функцій. Досягнути це можна за допомогою: активного впровадження ефективних новітніх технологій від посіву лісів до проведення лісозаготівель та деревообробки; удосконалення та автоматизації систем управління лісовим господарством, лісовпорядкування, інвентаризації та моніторингу стану лісів; забезпечення безпечних умов праці робітників у галузі лісового господарства; ведення лісового господарства на засадах сталого роз, витку.

На нашу думку, поліфункціональним інструментом досягнення вищевказаного, а звідси підвищення ефективності господарської діяльності підприємств в сфері лісового господарства можна досягти саме за допомогою безпілотних літальних апаратів.Україна входить в десятку найбільших світових виробників безпілотних літальних апаратів (БПЛА). За оцінками Gartner, до 2020 року оборот світового ринку БПЛА перевищить \$11,2 млрд. У 2017 році він оцінювався в \$7,8 млрд, роком раніше - у \$7,3 млрд. Такі дані наводяться у звітах аналітиків J'son \& Partners Consulting. За їхніми підрахунками, у 2017 році військові дрони утримували 53\% ринку в грошовому вираженні і лише 0,5\% - у натуральному. Така істотна різниця пояснюється тим, що бойові дрони в середньому коштують у 200 разів дорожче, ніж цивільні БПЛА.

Дрони цивільного призначення поділяють на споживчі i комерційні (промислові). У 2017 році частка першого сегмента оцінювалася J'son \& Partners Consulting у 23\% в грошах і 84\% в штуках. Другого - 24\% і 15\% відповідно [9].

Інтенсивність ведення лісового господарства, як правило, посилюється для досягнення або економічних критеріїв (збільшення врожаю деревини, недеревних лісопродуктів, екосистемних послуг) або екологічних критеріїв (відновлення видів, вирощування рідкісних видів, поглинання вуглецю 
Більшість лісів Свропи мають плани господарювання; з іншого боку, плани господарювання існують для менш ніж 25 відсотків лісів в Африці та менш ніж 20 відсотків у Південній Америці. Площа лісів за планами управління збільшується у всіх регіонах - у всьому світі вона збільшилася на 233 млн га 3 2000 р., Досягнувши 2,05 млрд га у 2020 р[10].

Для належного управління та контролю лісів необхідно створити самостійне лісове господарство. Тому утримання та контроль за лісами, які перебувають у власності заповідників, стає важливим питанням.

Відповідно, важливо сприяти ефективній діяльності шляхом розширення масштабів господарювання та запобігання поділу лісової власності та управління шляхом придбання лісових земель та сприяння єдиному управлінню, наприклад шляхом введення в дію лісового господарства спільно для кількох лісів.

Крім того, для забезпечення самостійності керівництва лісового господарства, крім виробництва недеревних лісових продуктів, таких як гриби та їстівні дикорослі рослини, необхідно сприяти різноманітному управлінню, такому як розширення бізнес-цілей, включаючи відпочинок у лісі або обробка та продаж столярних виробів. У такому випадку важливо виховувати органи управління лісовим господарством, щоб стати зразковими власниками лісів у громаді, з технічних та управлінських аспектів, здійснюючи власне управління та мати можливість брати на себе місцеве лісове виробництво.

Уряди також часто надають прямі чи непрямі субсидії іншим секторам, які можуть мати великий вплив на спосіб управління лісами. Так, наприклад, уряди часто використовують субсидії на користь аграрного сектору. Підвищення рентабельності в сільському господарстві може збільшити попит на землю i, якщо землі бракує, збільшити тиск на перетворення лісової землі.

Вплив субсидій на сільське господарство залежить від того, чи призведе така політика до інтенсифікації чи екстенсифікації сільського господарства. Це також залежить від таких факторів, як прийняті технології, економічні умови, з якими стикаються фермери, та характер субсидій. Через це не всі субсидії обов'язково призводять до посилення тиску на лісову землю. Субсидійне зрошення, швидше за все, призведе до інтенсифікації сільського господарства, оскільки зазвичай не зручно зрошувати віддалені ділянки на кордоні лісу. Субсидоване паливо та транспортна інфраструктура мають протилежний ефект, оскільки ці субсидії роблять більш вигідним використання віддалених лісових угідь. Субсидії, що стимулюють розвиток тваринництва, також, ймовірно, посилять тиск щодо перетворення лісових угідь на таке використання.

Однак у деяких випадках навіть субсидії, які призводять до інтенсифікації сільського господарства, можуть опосередковано посилити тиск на використання лісів у нестабільних способах. Наприклад, щедрі державні стимули призвели до зростання цін на землю в Південній Бразилії протягом 1970 -х та 1980 -х років. Така політика стимулювання заохочувала концентрацію земельної власності, інтенсифікацію сільського господарства та запровадження 
капіталомістких методів виробництва. Все це призвело до зростання безробіття. Деякі працівники, переміщені через механізацію та концентрацію власності на землю, мігрували до лісистих прикордонних районів в Амазонії, і це призвело до зростання тиску на використання лісових ресурсів таким чином, що призвело до виснаження [10].

У Канаді планування ведення лісового господарства $є$ одним 3 основних інструментів, що гарантують, що ліси, що знаходяться у державній власності країни, залишаються здоровими та енергійними, а також раціонально управляються ними.

Ключовим у цьому підході $є$ план ведення лісового господарства, який кожне лісове підприємство повинне скласти і затвердити урядом до початку збирання врожаю на громадських землях.

У Канаді більшість лісозаготівель у державних лісах здійснюють приватні лісогосподарські компанії. Компанії працюють за ліцензією або угодою про постачання деревини, яку вони мають 3 провінційним або територіальним урядом, який має юрисдикцію над землею . Ці лісові ліцензії та угоди висувають суворі вимоги до компаній.

Перед тим, як компанія може розпочати будь -які заготівлі або інші операції, вона повинна розробити лісогосподарський план та затвердити його. Дозвіл на заготівлю дерев на державних землях ніколи не відбувається автоматично. Розробка планів управління відбувається за суворим процесом, який, хоч i відрізняється залежно від юрисдикції, зазвичай передбачає отримання подання від промисловості, державних установ, громадськості та інших зацікавлених сторін. Метою є забезпечення того, щоб лісогосподарські операції та пов'язані 3 ними заходи здійснювалися таким чином, щоб підтримувати стале управління всіма лісовими ресурсами для майбутніх поколінь[11].

Окрім планів лісового господарства, більш детальні тактичні плани (наприклад, для орієнтування на графіки будівництва доріг та збирання врожаю) складаються для конкретних територій експлуатації та розширюються на період років. Крім того, щорічні операційні плани точно визначають, де і як збиральні роботи та відновлювальні роботи мають відбуватися в певні роки. Участь громадськості забезпечує прозорість процесу планування та надає канадцям реальний вплив у прийнятті рішень. Процеси участі громадськості варіюються від юрисдикції до юрисдикції, але сторони зазвичай включають:

- Корінні народи

- промислові та екологічні групи

- представники громади

У багатьох провінціях консультативні групи мають бути залучені до планування лісового господарства на громадських землях, а плани мають бути доступними для громадськості для перегляду та коментарів.

Звичайно, що важливим $є$ аналіз лісових ресурсів на основі глобальної 
оцінки. Так, в таблиці 1. [10] представлено обсяг лісу деяких країн світу.

Таблиияя 1.

Обсяг лісу,1990-2020

\begin{tabular}{|c|c|c|c|c|c|c|c|c|c|c|}
\hline \multirow[t]{3}{*}{ Країна } & \multicolumn{4}{|c|}{ Лісова площа (1000 га) } & \multicolumn{6}{|c|}{ Чиста річна зміна } \\
\hline & \multirow[t]{2}{*}{1990} & \multirow{2}{*}{2000} & \multirow[t]{2}{*}{2010} & \multirow{2}{*}{2020} & \multicolumn{2}{|c|}{$1990-2000$} & \multicolumn{2}{|c|}{$2000-2010$} & \multicolumn{2}{|c|}{$2010-2020$} \\
\hline & & & & & $\begin{array}{l}\text { 1000го } \\
/ \text { рік }\end{array}$ & $\%$ & $\begin{array}{l}\text { 1000го/ } \\
\text { рік }\end{array}$ & $\%$ & $\begin{array}{l}\text { 1000го/ } \\
\text { рік }\end{array}$ & $\%$ \\
\hline Австрія & 133882 & 131814 & 129546 & 134005 & -206.8 & -0.16 & -226.8 & -0.17 & 445.9 & 0.34 \\
\hline Білорусь & 7780 & 8273 & 8630 & 8768 & 49.3 & 0.62 & 35.7 & 0.42 & 13.8 & 0.16 \\
\hline Болівія & 57805 & 55101 & 53086 & 50834 & -270.3 & -0.48 & -201.5 & -0.37 & -225.2 & -0.43 \\
\hline Бразилія & 588898 & 551089 & 511581 & 496620 & -3780.9 & -0.66 & -3950.8 & -0.74 & -1496 & -0.30 \\
\hline Канада & 348273 & 347802 & 347322 & 346928 & -47.1 & -0.01 & -48.0 & -0.01 & -39.4 & -0.01 \\
\hline Китай & 157141 & 177001 & 200610 & 219978 & 1986.0 & 1.20 & 2361.0 & 1.26 & 1936.8 & 0.93 \\
\hline Конго & 22315 & 22195 & 22075 & 21946 & -12.0 & -0.05 & -12.0 & -0.05 & -12.9 & -0.06 \\
\hline Німеччина & 11300 & 11354 & 11409 & 11419 & 5.4 & 0.05 & 5.5 & 0.05 & 1,0 & 0.01 \\
\hline Індонезія & 118545 & 101280 & 99659 & 92133 & -1726.5 & -1.56 & -162.1 & -0.16 & -752.6 & $\begin{array}{l}-0.78 \\
\end{array}$ \\
\hline Індія & 63938 & 67591 & 69496 & 72160 & 365.3 & 0.56 & 190.5 & 0.28 & 266.4 & 0.38 \\
\hline Мексика & 70592 & 68381 & 66943 & 65692 & -221.0 & -0.32 & -143.8 & -0.21 & -125.1 & -0.19 \\
\hline Мозамбік & 43378 & 41188 & 38972 & 36744 & -219.0 & -0.52 & -221.6 & -0.55 & -222.8 & 0.59 \\
\hline Україна & 9274 & 9510 & 9548 & 9690 & 23.6 & 0.25 & 3.8 & 0.04 & 14.2 & 0.15 \\
\hline США & 302450 & 303536 & 308720 & 309795 & 108.6 & 0.04 & 518.4 & 0.17 & 107.5 & 0.03 \\
\hline
\end{tabular}

Отже, як видно з таблиці 1., спостерігається позитивна тенденція до росту лісових насаджень у багатьох країнах світу.

У своїх зусиллях сприяти економічному зростанню багато країн впровадили політику структурної перебудови (ПДП). Ця політика часто призводить до скорочення державних витрат та персоналу лісового господарства, сприяння приватизації, лібералізації валютних потоків та міжнародного руху капіталу, скасування іншої обмежувальної торговельної політики та, загалом, зменшення ролі держава [12]

Вплив цієї політики на спроби впровадження сталого лісового господарства наразі невизначений. Деякі сили, спровоковані або стимульовані впровадженням ПДП, можуть призвести до перетворення лісу, а інші можуть створити більш сприятливі умови для сталого управління лісами.

Наприклад, політика лібералізації торгівлі та іноземної валюти зазвичай покращує умови торгівлі сільським господарством у тропічних країнах, і це може зменшити стимули до інвестування у лісове господарство та посилити тиск щодо перетворення лісових земель у сільськогосподарське використання. Детальні дослідження впливу САП у: Болівії; Камерун; та Індонезії, припускають, що девальвація мала різний вплив, створюючи найбільш інтенсивний тиск на лісові ресурси, коли конкурентне використання лісових угідь-це діяльність, орієнтована на експорт [10].

Протягом останніх кількох років політика лібералізації, а також глобалізація світової економіки викликали занепокоєння, що недобросовісні та потужні 
перехідні корпорації з поганим рівнем екологічного чи соціального управління можуть скористатися перевагами слабких та безгрошових лісових країн та розширити свої нежиттєздатні операції, що принижують ресурси, на ці країни.

Незаконні та корупційні операції, ймовірно, матимуть важливий вплив на ліси, оскільки вони збільшують інвестиційні ризики і таким чином зменшують готовність інвесторів впроваджувати методи сталого управління лісами. Корупція послаблює адміністративний апарат держави, оскільки рішення починають упереджувати діяльність, яка не притягує хабарі. Крім того, оскільки уряд позбавлений доходів, які в іншому випадку могли б піти на покращення державно-адміністративних процедур та підтримку сталого лісового господарства, корупція створює стимули для організації лісозаготівель «вирубки».

Реформи політики щодо боротьби з корупцією покладаються на посилення контролю громадськості щодо рішень уряду, які спростять пошук і відстеження незаконних операцій та корупції. Процедури, які можна більш інтенсивно використовувати для зменшення масштабів корупції у лісовому секторі, включають: публічні торги за контрактами; регулярна ротація персоналу, відповідального за контракти; часті та непередбачені перевірки та аудит; та створення незалежних інспекторів. Зменшуючи корупцію, такі заходи підвищили б шанси, що ліси будуть управлятися більш стійкими способами.

Висновки. Лісове господарство в більшості країн продовжує адаптуватися до поточних тенденцій і передбачати майбутні зміни. Останні результати в досягненні більш високих показників відновлення в деяких випадках призвели до значного скорочення кількості деревини, заготовленої 3 лісів. Збільшення споживання лісової продукції, попит на продукцію вищої якості, зміни в доступності сировини та тиск громадськості щодо екологічних аспектів лісового господарства, виробництва та переробки залишатимуться основними факторами, що впливають на технології та розвиток продукції. Зміни в країнах, що розвиваються, пов'язані з більш фундаментальними тенденціями, як у лісовому секторі, так і за його межами, включаючи: заборону експорту колоди та швидкий перехід до виробництва продукції з доданою вартістю у все більшій кількості тропічних і нетропічних країн.

У промислово розвинених країнах інституційні потреби лісового господарства задовольняються установами, які, як правило, мають достатні кошти та достатньо спроможний професійний персонал для виконання своїх обов’язків. Найбільш помітні інституційні проблеми в цих країнах були пов'язані 3 негнучкістю лісових інституцій змінюватись у міру розвитку вимог суспільства. Це символізується суперечкою про плямисту сову, а також нинішніми дебатами про "вирубку лісу" в Тихоокеанському північно -західному регіоні Сполучених Штатів Америки. В інших випадках інституційна нездатність впоратися 3 вимогами сталого лісового господарства більше пов'язана 3 руйнівними наслідками політичних змін. 
У країнах, що розвиваються, ситуація зовсім інша. Тут загалом слабкі уряди повинні зіткнутися 3 тими самими інтенсивними інституційними вимогами для управління великими лісовими просторами. Однак каталог інституційних недоліків, які зараз переважають у багатьох країнах, що розвиваються, довгий і включає, наприклад:

· неадекватна дослідницька база;

- Недостатня кількість підготовлених посадових осіб;

. Слабкі міжгалузеві інституційні зв'язки;

- Недоліки планування; і

- Недостатнє фінансування.

Як наслідок, уряди цих країн часто не можуть ефективно розпоряджатися своїми лісовими ресурсами (тобто державними лісами), i, натомість, мають тенденцію передавати ці операції у контракти приватним концесіонерам. Передбачається, що ця домовленість планується та контролюється державою, але насправді ці механізми часто пошкоджуються, що призводить до неефективного моніторингу або, іноді, до повної відсутності контролю.

\section{Jimepamypa:}

1. Williams, M., E.B. Rastetter, D.N. Fernanades, M.L. Goulden, L.C. Johnson, G.R. Shaver. Predicting gross primary productivity in terrestrial ecosystems. Ecol. Appl. 1997.№ 7: c. 882-894. URL: https://www.jstor.org/stable/2269440

2. Reid J., Rice R. Economic Analysis of the Proposed Timber Concession at Arroyo, Colorado: Are There Incentives for Management? Conservation International, Washington, 1994. №25, c.111-112.

3. Kishor N., Constantino L., Forest Management and Competing Land Uses: An Economic Analysis for Costa Rica. LATEN Dissemination Note. Washington . 1993. №7. C. 46-50.

4. Данилишин Б. М. Наукові нариси з економіки природокористування : монографія / Б. М. Данилишин. - Київ : РВПС України НАН України, 2008. - 280 с.

5. Природно-ресурсна сфера України: проблеми сталого розвитку та трансформацій / за заг. ред. Б. М. Данилишина. - Київ : НІЧЛАВА, 2006. - 704 с.

6. Ветвицький Д. О. Роль держави у раціональному використанні природних ресурсів та охорони довкілля щодо забезпечення якості життя / Д. О. Ветвицький // Наук. вісн. Акад. муніцип. упр. Сер. «Управління». - 2010. - Вип. 2. - С. 233 - 239.

7. Дутка С. М. Розвиток енергозбереження в умовах ринкового господарювання на малопродуктивних землях : автореф. дис. ... канд. екон. наук : 08.00 .04 / Дутка С. М. Дніпропетровськ : Дніпропетр. Держ. аграр. ун-т. - 2008. - 24 с.

8. Тенденції в управлінні та використанні лісів. URL: https://www.fao.org/3/w4345e/ w4345e04.htm

9. Небесний патруль. URL: https://nubip.edu.ua/en/node/71824

10.Глобальна оцінка лісових ресурсів 2020 - Основні висновки . / звіт ФАО. Рим: 2020,.50с.

11. Forest management planning. URL: https://www.nrcan.gc.ca/our-naturalresources/forests-forestry/sustainable-forest-management/forest-management-planning/17493

12. Світовий банк. URL: https://www.worldbank.org/uk/country/ukraine

\section{References:}

1. Williams, M., E.B. Rastetter, D.N. Fernanades, M.L. Goulden, L.C. Johnson, G.R. Shaver. Predicting gross primary productivity in terrestrial ecosystems. Ecol. Appl. 1997.№ 7: c. 882-894. URL: https://www.jstor.org/stable/2269440 
2. Reid J., Rice R. Economic Analysis of the Proposed Timber Concession at Arroyo, Colorado: Are There Incentives for Management? Conservation International, Washington, 1994. №25, c.111-112.

3. Kishor N., Constantino L., Forest Management and Competing Land Uses: An Economic Analysis for Costa Rica. LATEN Dissemination Note . Washington . 1993. №7. C. 46-50.

4. Danilishin, B. M. (2008). Naukovi narisi z ekonomiki prirodokoristuvannja [Scientific essays on the economics of nature]. Kiïv : RVPS Ukraïni HAH Ukraïni [in Ukrainian].

5. Danilishin, B. M. (2006). Prirodno-resursna sfera Ukraïni: problemi stalogo rozvitku ta transformacij [Natural resource sphere of Ukraine: problems of sustainable development and transformation]. Kiïv : NIChLAVA [in Ukrainian].

6. Vetvic'kij, D. O. (2010). Rol' derzhavi u racional'nomu vikoristanni prirodnih resursiv ta ohoroni dovkillja shhodo zabezpechennja jakosti zhittja [The role of the state in the rational use of natural resources and environmental protection to ensure the quality of life]. Nauk. visn. Akad. municip. upr. Ser. «Upravlinnja» - Nauk. spring Acad. municipality. ynp. Ser. "Management", 2, 233 - 239 [in Ukrainian].

7. Dutka, S. M. (2008). Rozvitok energozberezhennja v umovah rinkovogo gospodarjuvannja na maloproduktivnih zemljah [Development of energy saving in the conditions of market economy on lowproductive lands] . Extended abstract of candidate's thesis. Dnipropetr. Derzh. agrar. un-t. [in Ukrainian]

8. Tendenciï v upravlinni ta vikoristanni lisiv. URL: https://www.fao.org/3/w4345e/ w4345e04.htm [in Ukrainian]

9. Nebesnij patrul'. URL: https://nubip.edu.ua/en/node/71824 [in Ukrainian]

10. Global'na ocinka lisovih resursiv 2020 - Osnovni visnovki . / zvit FAO. Rim: 2020,ju.50s. [in Ukrainian]

11. Forest management planning. URL: https://www.nrcan.gc.ca/our-natural-resources/forestsforestry/sustainable-forest-management/forest-management-planning/17493

12. Svitovij bank. URL: https://www.worldbank.org/uk/country/ukraine [in Ukrainian] 